\title{
Genotyping-by-Sequencing for the Study of Genetic Diversity in Puccinia triticina
}

\author{
Meriem Aoun, ${ }^{1}$ James A. Kolmer, ${ }^{2,3}$ Matthew Breiland, ${ }^{1}$ Jonathan Richards, ${ }^{1}$ Robert S. Brueggeman, ${ }^{1}$ Les J. Szabo, ${ }^{2,3}$ \\ and Maricelis Acevedo ${ }^{4, \dagger}$ \\ ${ }^{1}$ Department of Plant Pathology, North Dakota State University, Fargo, ND, 58108 \\ ${ }^{2}$ United States Department of Agriculture-Agricultural Research Service (USDA-ARS), Cereal Disease Laboratory, St. Paul, \\ MN 55108 \\ ${ }^{3}$ Department of Plant Pathology, University of Minnesota, St. Paul, MN 55108 \\ ${ }^{4}$ International Programs, College of Agriculture and Life Sciences, Cornell University, Ithaca, NY
}

\begin{abstract}
Leaf rust, caused by Puccinia triticina Erikss., is globally the most widespread rust of wheat. Populations of $P$. triticina are highly diverse for virulence, with many different races found annually. The genetic diversity of $P$. triticina populations has been previously assessed using different types of DNA markers. Genotyping technologies that provide a higher density of markers distributed across the genome will be more powerful for analysis of genetic and phylogenetic relationships in P. triticina populations. In this study, we utilized restrictionassociated DNA (RAD) genotyping-by-sequencing (GBS) adapted for the Ion Torrent sequencing platform for the study of population diversity in $P$. triticina. A collection of 102 isolates, collected mainly from tetraploid and hexaploid wheat, was used. The virulence phenotypes of the isolates were determined on 20 lines of Thatcher wheat near isogenic for leaf rust resistance genes. Seven races were found

study to report durum wheat virulent races to $L r 3 b g$ in Tunisia, Lr14a in Morocco, and Lr3bg and Lr28 in Mexico. Ethiopian isolates with high virulence to durum wheat but avirulent on Thatcher (hexaploid wheat) were tested for virulence on a set of durum (tetraploid) differentials. A subset of 30 isolates representing most of the virulence phenotypes in the 102 isolates were genotyped using RAD-GBS. Phylogenetic analysis of 30 isolates using 2,125 single nucleotide polymorphism (SNP) markers showed nine distinct clusters. There was a general correlation between virulence phenotypes and SNP genotypes. The high bootstrap values between clusters of isolates in the phylogenetic tree indicated that RAD-GBS can be used as a new genotyping tool that is fast, simple, high throughput, cost effective, and provides a sufficient number of markers for the study of genetic diversity in P. triticina.
\end{abstract} among 57 isolates collected from tetraploid wheat, and 21 races were observed among 40 hexaploid wheat type isolates. This is the first
Keywords: pathogen diversity, fungi, field crops, cereals and grains
Leaf rust is a common disease in all wheat (Triticum spp.) growing regions and is the most commonly found of the three wheat rusts (Chester 1946), reducing the quantity and quality of kernels. The severity of leaf rust is usually the highest in areas where wheat grows under warm to hot climates such as the Great Plains of North America and the steppes of Central Asia. Similarly, high leaf rust severity has also been reported in regions with warm and humid climate such as the Mediterranean basin, South America, and the coastal regions of North America (Liu et al. 2014). Leaf rust is found on hexaploid common wheat (Triticum aestivum L.) globally, whereas leaf rust occurs on tetraploid durum wheat (Triticum turgidum L. var. durum) mainly in the Mediterranean basin, Middle East, Ethiopia, Mexico, and South America (Ordoñez and Kolmer 2007a).

Puccinia triticina is a macrocyclic-heteroecious rust, producing five spore stages. Wheat and wild relatives are the primary hosts on which urediniospores, teliospores, and basidiospores are produced. The pycniospores and aeciospores are produced on the alternate hosts, mainly Thalictrum speciosissimum L. (Mains and Jackson 1921), which is native to Spain and Portugal, where the sexual cycle has been observed. In addition, sexual reproduction on Thalictrum

${ }^{\dagger}$ Corresponding author: M. Acevedo; ma934@ cornell.edu

Funding: This work was supported by the North Dakota Wheat Commission, ND SBARE grants program, and the Delivering Genetic Gain in Wheat Project (Bill and Melinda Gates Foundation grant number OPP1133199).

The author(s) declare no conflict of interest.

Accepted for publication 4 October 2019. distributed under the CC BY 4.0 International license. spp. was observed in northeast Kazakhstan (J. A. Kolmer, unpublished data) and in Siberia on Isopyrum fumarioides (Chester 1946). Because susceptible alternate hosts are absent in many parts of the world, $P$. triticina reproduces mainly by clonal production of dikaryotic urediniospores.

Despite the rare contribution of sexual recombination, $P$. triticina population continues to evolve asexually and shows high diversity for virulence to leaf rust resistance $(L r)$ genes in wheat (Kolmer 2013; McCallum et al. 2007; Roelfs et al. 1992). Over 50 virulence phenotypes are detected annually in North America (Kolmer 2013; Kolmer and Hughes 2016; McCallum et al. 2007). Genetic drift, migration, and host selection contribute to genetic diversity in $P$. triticina populations, and parasexual recombination in $P$. triticina has also been reported in Australia (Park et al. 1999). Mutation is the primary source of $P$. triticina diversity, resulting in the rapid appearance of virulent races in response to the use of wheat cultivars with effective leaf rust resistance genes (Ordoñez and Kolmer 2007a).

In recent years, $P$. triticina races highly virulent on durum wheat (Goyeau et al. 2006; Martinez et al. 2005; Ordoñez and Kolmer 2007a; Singh et al. 2004) have spread to most of the durum producing regions of the world. As a result, many durum wheat cultivars are now susceptible to leaf rust. Isolates of $P$. triticina virulent on durum wheat are avirulent to most of the $L r$ genes identified in common (hexaploid) wheat (Goyeau et al. 2006; Ordoñez and Kolmer 2007b). In addition, $P$. triticina isolates collected from durum wheat are less diverse for virulence phenotypes and simple sequence repeat (SSR) genotypes compared with those collected from common wheat (Goyeau et al. 2012; Kolmer and Acevedo 2016; Martinez et al. 2005; Ordoñez and Kolmer 2007a, 2007b). Isolates of $P$. triticina virulent on durum wheat in Mexico (Singh et al. 2004) were very similar for virulence phenotypes and SSR genotypes to isolates collected on durum wheat in Spain, France, Mexico, Argentina, and the United States, suggesting a common ancestor (Ordoñez and Kolmer 
2007a, 2007b). However, some $P$. triticina isolates collected in Ethiopia on tetraploid wheat had a virulence phenotype and SSR genotype distinct from all other worldwide collections of isolates from both durum and common wheat (Kolmer and Acevedo 2016). These Ethiopian durum-specific isolates are avirulent to leaf rust susceptible common wheat cultivars such as Thatcher and Little Club.

Over the last 20 years, molecular markers have been used to assess genetic diversity in $P$. triticina populations. Random amplified polymorphism of DNA markers were the first used to genotype $P$. triticina populations (Kolmer et al. 1995; Kolmer and Liu 2000; Park et al. 2000), followed by amplified fragment-length polymorphisms (AFLPs) (Kolmer 2001) and then by SSRs (Duan et al. 2003). A set of 23 SSRs (Kolmer et al. 2019; Ordoñez et al. 2010; Szabo and Kolmer 2007) have been used in studies to assess the genetic diversity of clonal populations of $P$. triticina. Moderate correlation between SSR genotypes and virulence phenotypes has been observed (Kolmer 2015; Kolmer and Acevedo 2016; Kolmer et al. 2011, 2013; Ordoñez and Kolmer 2007b, 2009; Ordoñez et al. 2010).

Population genetic studies require high numbers of markers in order to draw reliable inferences regarding the genetic relatedness of different population groups. A large number of single nucleotide polymorphic (SNP) markers can be obtained with the genotypingby-sequencing (GBS) method. GBS is a low-cost approach used to achieve a reduced-complexity sequence of the whole genome by targeting subsets of genomic regions (Elshire et al. 2011; Poland et al. 2012a). This technique has been used in several studies involving genomic selection, genetic mapping, dissecting the genetic basis of disease resistance traits, and genetic diversity studies in several organisms (Adhikari and Missaoui 2019; Elshire et al. 2011; Li et al. 2015; Lu et al. 2013; Poland et al. 2012a, 2012b). Restrictionassociated DNA GBS (RAD-GBS) uses restriction enzymes to capture targeted regions of the genome. Adaptors are ligated to the flanking regions of the restriction sites to create barcoded libraries, which allows the sequencing of several individuals at a time (Mascher et al. 2013). The RAD-GBS method has mainly been based on Illumina GAII and HiSeq platforms (Poland and Rife 2012). However, recently an optimized RAD-GBS protocol, adapted for the Ion Torrent platform, has become available (Rothberg et al. 2011) and has been used to generate sufficient genotyping density for a number of plant pathogens (Carlsen et al. 2017; Gao et al. 2016; Leboldus et al. 2015). The reference genome of $P$. triticina (https://www.broadinstitute.org/annotation/genome/puccinia_group/Downloads.html) allowed mapping of the RAD-GBS generated SNPs to specific locations on contigs. We hypothesized that the use of high-density SNPs across the $P$. triticina genome will provide better precision in the study of genetic diversity of this pathogen. The objectives of this study were to (i) assess the application of RAD-GBS using the Ion Torrent sequencing platform as a new genotyping tool for the study of genetic diversity in $P$. triticina and (ii) develop durum differential lines to distinguish between virulence phenotypes of Ethiopian isolates that are avirulent to Thatcher wheat.

\section{Materials and Methods}

Puccinia triticina isolates. Forty-five samples of wheat leaves infected with $P$. triticina were received from Morocco, Tunisia, Spain, and Ethiopia. Each sample corresponds to multiple leaves with leaf rust infections, collected from a single plant. Sampling was done randomly in the field. A set of 12 samples was collected in 2014 from research plots of durum wheat, common wheat, and cultivated emmer at the Debre Zeit Agricultural Research Center (DZARC), Ethiopia. A second set of eight samples were collected in 2014 in Spain from common wheat, durum wheat, and triticale fields at Peralta, Learza (Navarra), Huesca, Coril (Cadiz), and Jerez de la Frontera locations. Six samples were also collected in 2014 in Tunisia from research plots of common wheat, durum wheat, and triticale at the National Institute of Agronomic Research of Tunisia (INRAT), Beja experiment station, Grombalia, and Mateur. An additional 19 samples were collected in Morocco in 2014 and 2015 from durum wheat and common wheat fields at Zemamra, Jemaa-Shaam, Rabat, Marchouch, and Tahrir. The samples (infected leaves) were placed in paper envelopes and air dried at room temperature. The samples were then shipped to North Dakota State University, where they were stored at $-80^{\circ} \mathrm{C}$ until processed.

The samples were processed during winter months (December to February) at the North Dakota Agricultural Experiment Station Greenhouse Complex (ND-AESGC), Fargo, ND. Urediniospores from each sample were collected using a cotton swab immersed in Soltrol-170 mineral oil (Phillips Petroleum). The swab containing the collected spores was used to inoculate 7-day-old seedlings of the leaf-rust-susceptible durum wheat line RL6089 for spore increase. The seedlings were treated with a $0.3 \%$ solution of maleic hydrazide to increase sporulation and prevent secondary leaves from forming (Goyeau et al. 2006). Seven days after inoculation, spores from a single uredinium were collected with a cotton swab, which was in turn used to inoculate seedlings of RL6089 and Thatcher for increase of the purified single-uredinium isolates. From each sample, one to four single-uredinial isolations were derived. The singleuredinial isolates were increased on seedlings and covered with an isolation box to avoid cross-contamination. Incubation and greenhouse conditions were as described by Aoun et al. (2016).

A total of 86 single-uredinial isolates were obtained from the samples collected in Ethiopia, Morocco, Spain, and Tunisia. Seven more single-uredinial isolates from Mexico (collected in 2001 to 2014) were acquired from CIMMYT-Mexico. Five isolates from Chile (collected in 2013) and five isolates from Pakistan (collected in 2013 and 2014) were acquired from the USDA-ARS Cereal Disease Laboratory (USDA-CDL) in St. Paul, MN. In addition, two isolates from the United States, race 1 and CA1.2, were included in the analysis for comparison. Race1 is a North American common wheat type race and was used in this study as a control because its whole genome sequence is available; isolate CA1.2 was collected on durum wheat in California in 2009. In total, 102 single-pustule isolates were used for this study, with 51 collected from durum wheat, 40 from common wheat, five from triticale, and six from cultivated emmer wheat (Triticum dicoccum) (Table 1).

Virulence phenotypes of $\boldsymbol{P}$. triticina isolates. Urediniospores of each of the 102 single-uredinial isolates were increased to generate enough inoculum for virulence phenotyping and DNA extraction. Eighty-one isolates were phenotyped at the USDA-CDL, and the remaining 21 isolates were phenotyped at ND-AESGC, Fargo, ND. Five sets of four Thatcher wheat near-isogenic lines (NILs) carrying different $L r$ genes were used for the isolate phenotyping. The first set included lines with genes $L r 1$ (isogenic line RL6003), $L r 2 a$ (RL6000), Lr2c (RL6047), and Lr3a (RL6002); the second set included lines with genes Lr9 (RL6010), Lr16 (RL6005), Lr24 (RL 6064), and $\operatorname{Lr} 26$ (6078); the third set comprised lines with genes Lr3ka (RL6007), Lr11 (RL6053), Lr17 (RL6008), and Lr30 (RL6049); the fourth set included lines with genes $\operatorname{LrB}$ (RL6047), Lr10 (RL6004), Lr14a (RL6013), and Lr18 (RL6009); and the fifth set had lines carrying genes Lr3bg (RL6042), Lr14b (RL6006), Lr20 (RL 6092), and Lr28 (RL6079). Thatcher was included as a check. The plants were inoculated at the first-leaf stage ( 7 to 8 days after planting) with fresh urediniospores suspended in Soltrol-170 mineral oil (Phillips Petroleum) using an inoculator pressurized by an air pump. The inoculated plants were then placed in a mist chamber overnight and later transferred and kept in the greenhouse at 18 to $25^{\circ} \mathrm{C}$ and a $16-\mathrm{h}$ photoperiod. The seedlings were evaluated for infection types (ITs) 10 to 12 days after inoculation. At ND-AESGC, Fargo, ND, the virulence phenotype of these isolates was based on two replicates per isolate. The virulence phenotypes of the isolates, at the USDA-CDL, MN, was based on single tests. However, in the case in which disease development or plant development was suboptimal and ITs were difficult to determine, a second test was performed. Seedlings showing ITs of 0 to $2^{+}$and mesothetic reaction (or " $\mathrm{X}$ " reaction) were classified as resistant, whereas those showing ITs of 3 to 4 were classified as susceptible. Based on the ITs on the isogenic lines, a five-letter designation was assigned to each isolate following the nomenclature of Long and Kolmer (1989).

Some of the Ethiopian isolates with high virulence to durum wheat that were avirulent on Thatcher were given the race code EEEEE, 
because these isolates could not be phenotyped for virulence with the Thatcher NILs. To be able to determine potential virulence differences across these isolates, seven Ethiopian EEEEE isolates were tested on a set of 23 durum wheat accessions using Thatcher as a resistant control. Twelve of these accessions were selected from the USDA National Small Grain Collection (NSGC) of durum wheat, because these showed resistance to several $P$. triticina isolates in previous studies (Aoun et al. 2016, 2017, 2019). The 12 accessions were PI 45442, PI 192051, PI 195693, PI 209274, PI 244061, PI 278379, PI 313096, PI 324928, PI 342647, PI 387263, PI 519832, and PI 534304. The remaining 11 genotypes were durum cultivars 'Divide', 'Rusty', 'Capelli', 'Mindum', 'Russello S.G.7', 'Alred', 'Creso' with Lr14c, 'Llareta INIA' (Lr14a), 'Camayo' (LrCamayo), 'Jupare C2001' (Lr27+Lr31), and 'Mexicali 75'.

DNA extraction, library preparation, and sequencing. A total of 44 isolates, selected from the 102 isolates, representing diverse virulence phenotypes and collected from different hosts and countries, were chosen for genotyping. These isolates included two from the United States, four from Mexico, five from Chile, five from Pakistan, four from Ethiopia, six from Tunisia, eight from Morocco, and 10 from Spain. Twenty-one isolates from common wheat, 17 from durum wheat, four from triticale, and two from emmer wheat were genotyped (Table 2).

For the 12 isolates obtained from the USDA-CDL, $\sim 25 \mathrm{mg}$ of urediniospores from each isolate were germinated, and the fungal material was lyophilized and ground as described by Ordoñez and Kolmer (2007b). The DNA was extracted using an OmniPrep (GBioSciences) extraction kit according to the manufacturer's instructions. For the remaining 32 isolates, 20 to $30 \mathrm{mg}$ of urediniospores from each isolate were germinated at room temperature in a glass Petri dish containing $500 \mathrm{ml}$ of a germination solution $(499 \mathrm{ml}$ of Milli Q water and $1 \mathrm{ml}$ of $500 \times$ stock solution). The stock solution was made from $72 \mu \mathrm{l}$ of nonyl alcohol, $0.5 \mu \mathrm{l}$ of Tween $20,10 \mathrm{ml}$ of ethanol, and $10 \mathrm{ml}$ of distilled water (Barnstead International, Dubuque, IA) (Nirmala et al. 2011). The urediniospores were left to germinate overnight, and the DNA was extracted from the germinated spore mats using a cetyltrimethylammonium bromide protocol (Riede and Anderson 1996). The DNA of the 44 isolates was quantified using a Qubit2.0 fluorometer (Invitrogen, Life Technologies). In total, $250 \mathrm{ng}$ of DNA was used per isolate for genotyping.

For library preparation, the DNA from each isolate was digested with HhaI enzyme (NEB, Ipswich, MA) for $2 \mathrm{~h} 30 \mathrm{~min}$ at $37^{\circ} \mathrm{C}$. The samples were then digested with a second enzyme, ApeKI (NEB), for $2 \mathrm{~h} 30 \mathrm{~min}$ at $75^{\circ} \mathrm{C}$. The digested DNA was cleaned up using magnetic particles (Agencourt AMPure XP, manufactured by Seradyn). The DNA pellet was then washed twice with $75 \%$ ethanol and air dried, before resuspension in $\mathrm{H}_{2} \mathrm{O}$. Ligation reactions containing $3 \mu$ l of $10 \times$ ligase buffer (Promega, Madison, WI), 3 units of T4 DNA ligase (Promega), $100 \mu \mathrm{M}$ universal P1-Hhal adaptor, $4 \mu \mathrm{l}$ of $\mathrm{H}_{2} \mathrm{O}$, and $100 \mu \mathrm{M}$ ApeKI specific barcoded adaptor were added to $20 \mu \mathrm{l}$ of DNA of each isolate. The sequences of adaptors are as described by Leboldus et al. (2015). The ligation reaction was left for 16 to $20 \mathrm{~h}$ at $4^{\circ} \mathrm{C}$ and thereafter inactivated for $20 \mathrm{~min}$ at $65^{\circ} \mathrm{C}$. The uniformity of DNA concentration of all the reactions was checked on $1 \%$ agarose gel before the reactions were combined. Each 22 reactions (barcoded isolates) were combined into one sample. Unligated adaptors from the two pooled samples were removed using a PureLink Quick Gel Extraction and PCR Purification Combo kit (Invitrogen, Thermo Fisher Scientific). The two pooled samples each containing 22 isolates were then size selected for 275-bp fragments on $1.5 \%$ agarose cassettes using the Pippin Prep (Sage Science, Beverly, MA) size selection system. The size-selected samples were then amplified (GBS library) as described by Leboldus et al. (2015). The quality of PCR reactions was verified on $1 \%$ agarose gel before the two samples were normalized to a working concentration of $70 \mathrm{pM}$. The library sequencing was performed on an Ion Torrent PGM Sequencer (Life Technologies, Grand Island, NY) using two Ion 318 Microprocessor Chips for the two created samples (one chip per sample pool). The sequencing was performed following the Ion Torrent PGM sequencing protocol at the barley pathology laboratory at North Dakota State University, Fargo, ND.

Sequencing data analysis. The sequencing reads of each isolate were individually aligned to the $P$. triticina reference genome (race1-BBBD) available on the Broad Institute website (https:// www.broadinstitute.org/annotation/genome/puccinia_group/Downloads. html). This alignment was done using the Burrows-Wheeler Aligner "mem" algorithm with default settings ( $\mathrm{Li}$ and Durbin 2009). The SNP calling was conducted using the Genome Analysis Toolkit Unified Genotyper and subsequently filtered using "vcftools" for a minimum genotype quality of 10 and a minimum read depth per SNP per individual of three (Danecek et al. 2011; DePristo et al. 2011). The variant call format file was then imported into Golden Helix SNP \& Variation Suite software. SNPs and isolates with missing data $>10 \%$ were discarded. In addition, markers with minor allele frequency $<5 \%$ were eliminated from further analysis.

Neighbor-joining phylogenetic analysis. Data analysis was performed using R 3.4.1 (R Core Team 2017). The generated SNPs were used to create a neighbor-joining phylogenetic tree using the package "Poppr" (Kamvar et al. 2014), including Ape version 3.1-4 (Paradis et al. 2004), Adegenet version 1.4-2 (Jombart 2008), and Pegas version 0.6 (Paradis 2010). The neighbor-joining tree was generated using the following parameters: Nei's distance (Nei 1972, 1978), neighbor joining (Saitou and Nei 1987), and 5,000 bootstrap replicates with a cutoff of $75 \%$.

\section{Results}

Virulence phenotypes. Virulence phenotypes on Thatcher differential lines showed that races of $P$. triticina collected from tetraploid wheat (durum and emmer wheat) differ from those collected from hexaploid common wheat. Isolates with virulence on tetraploid wheat had fewer races compared with isolates found on common wheat (Table 2). In 57 isolates collected from tetraploid wheat, only seven races were observed, whereas in 40 isolates collected from common wheat, 21 races were identified. Therefore, one race per 1.9 isolates was found among $P$. triticina common wheat type isolates compared with one race per 8.14 isolates among $P$. triticina

Table 1. Number of single-uredinial isolates collected from different countries on durum wheat, common wheat, emmer wheat, and triticale

\begin{tabular}{|c|c|c|c|c|c|c|}
\hline \multirow[b]{2}{*}{ Country } & \multirow[b]{2}{*}{ Number of collections } & \multirow[b]{2}{*}{ Number of isolates } & \multicolumn{4}{|c|}{ Number of isolates per host species } \\
\hline & & & Common wheat & Durum wheat & Emmer wheat & Triticale \\
\hline Ethiopia & 12 & 17 & 1 & 10 & 6 & 0 \\
\hline Mexico & $-^{\mathrm{a}}$ & 7 & 2 & 5 & 0 & 0 \\
\hline Morocco & 19 & 32 & 14 & 18 & 0 & 0 \\
\hline Chile & $-\mathrm{a}$ & 5 & 3 & 2 & 0 & 0 \\
\hline Pakistan & $-^{\mathrm{a}}$ & 5 & 5 & 0 & 0 & 0 \\
\hline Spain & 8 & 21 & 12 & 5 & 0 & 4 \\
\hline Tunisia & 6 & 13 & 2 & 10 & 0 & 1 \\
\hline U.S.A. & $-^{\mathrm{a}}$ & 2 & 1 & 1 & 0 & 0 \\
\hline Total & 45 & 102 & 40 & 51 & 6 & 5 \\
\hline
\end{tabular}

a Single-uredinial isolates were obtained from collaborators. 
tetraploid wheat type isolates. In addition, tetraploid wheat type races showed virulence to a lower number of $L r$ genes (zero to five $L r$ genes). In contrast, the common wheat type races were virulent to many $L r$ genes.

Race EEEEE, which is avirulent on Thatcher wheat, was only collected from Ethiopia on durum wheat (10 isolates) and emmer wheat (six isolates). In Morocco and Chile, races BBBQJ and BBBSJ were among the isolates collected on durum wheat, indicating that virulence to $L r B, L r 10, L r 14 a, L r 14 b$, and $L r 20$ exists in these two countries. In Tunisia, the virulence phenotypes BBBQJ, BBBSJ, and BBBSQ were found among the isolates collected from durum wheat, showing that virulence to $\operatorname{LrB}, \mathrm{Lr} 3 b g, \mathrm{Lr} 10, \mathrm{Lr} 14 a, \operatorname{Lr} 14 b$, and $\mathrm{Lr} 20$ is present in Tunisia. In Spain, only BBBSJ was identified on durum wheat, with virulence to $L r B, L r 10, L r 14 a, L r 14 b$, and $L r 20$. Four races $(\mathrm{BBBQJ}, \mathrm{BBBQK}, \mathrm{BCBQJ}$, and $\mathrm{CBBQS}$ ) were observed on durum wheat in Mexico. Three of these races (BBBQK, BCBQJ, and $C B B Q S$ ) were not present in other countries. The Mexican races were virulent to $L r B, L r 3 a, L r 3 b g, L r 10, L r 14 b, L r 20, L r 26$, and $L r 28$. In the United States, the only described race on durum wheat was BBBQJ, with virulence to $L r B, L r 10, L r l 4 b$, and $L r 20$. Twenty-one races were observed in the isolates collected from common wheat across experimental sites. These common wheat type races were virulent to many of the Thatcher differential lines. Triticale isolates collected from Spain had virulence phenotypes CBGNQ, FBBPQ, and FBBNQ, and race FCBPQ was collected from triticale in Tunisia.

Durum differential lines for the Ethiopia durum wheat isolates. Unlike all other isolates collected for this study, race designations were not determined for the Ethiopian EEEEE isolates, because these unique isolates were avirulent on Thatcher. Further phenotyping of seven EEEEE isolates, collected from durum and emmer wheat, on a set of 23 durum accessions showed that there were virulence differences between the EEEEE isolates. Twelve durum accessions were resistant to all the seven EEEEE isolates, whereas Alred and Rusty were susceptible to all isolates. The remaining nine durum accessions (PI 209274, PI 244061, PI 278379, PI 387263, Mindum, Llareta INIA, Camayo, Mexicali 75, and Russello G.S.7) displayed differential reactions to the tested EEEEE isolates and were retained as differential lines (Table 3). Previous mapping studies showed that Llareta INIA, Camayo, PI 209274, PI 244061, and PI 387263 carry Lrl4a on chromosome arm 7BL (HerreraFoessel et al. 2008b), LrCamayo on chromosome 6BL (HerreraFoessel et al. 2007), LrPI 209274 on chromosome 6BS (Aoun et al. 2017), $\operatorname{LrPI} 244061$ on chromosome 2BS (Aoun et al. 2017), and LrPI 387263 on chromosome 6BL (Aoun et al. 2017), respectively. The $L r$ genes in the remaining four differential lines are unknown. Based on the virulence phenotypes on the nine durum differentials, each of the four isolates 50-4, 49-1, 57-2, and 65-2 had a unique virulence/avirulence profile. The remaining three isolates (63-1, 63-3, and 64-1) shared the same virulence/avirulence profile on the durum differentials (Table 3 ). Therefore, based on the durum differential set, five virulence phenotypes were found among the seven EEEEE isolates. This revealed that the EEEEE isolates are diverse for virulence on durum wheat genotypes.

Neighbor-joining phylogenetic analysis. Of the genotyped isolates, 30 were kept for further analysis after filtering missing data points, and 2,125 SNPs were retained. Of these 30 isolates, 18 were collected from common wheat, six from durum wheat, four from triticale, and two from emmer wheat. These isolates were of diverse origin, with eight from Spain, five each from Pakistan and Chile, three each from Mexico and Morocco, and two each from Ethiopia, Tunisia, and the United States.

Phylogenetic analysis using a neighbor-joining tree based on Nei's genetic distance grouped the 30 isolates into 10 clades with high bootstrap support values. The Nei's genetic distances between isolates ranged from 0.02 to 0.63 . The lowest Nei's genetic distance was observed between isolates CHL_03-D2_MCDSS and CHL_ 04-D2_MBDSS and between isolates PAK_1-2_BBBDH and PAK_1-3_BBBDH. The highest Nei's genetic distance was found between the isolates TUN_18_BBBSQ and MEX_12_TBDKT.
The phylogeny showed clustering based on the host from which the isolates were collected. Durum and emmer wheat isolates were clustered in two well-supported clades with $100 \%$ bootstrap values. The durum type phenotypes BBBQJ, BBBSJ, BBBSQ, and CBBQS were clustered in clade I, despite coming from Tunisia, Mexico, and Morocco. This suggests that these phenotypes may share a common origin. The two Ethiopian isolates with phenotype EEEEE were in clade II with a Nei's genetic distance of 0.34 . The isolates collected from triticale with virulence phenotypes FBBNQ, FBBPQ, CBGNQ, and FCBPQ from Tunisia and Spain were grouped in clade III. The isolate MEX_14_BBBQK (clade IV) was not clustered with the other durum type isolates in clade I. However, the bootstrap value associated with the MEX_14_BBBQK was lower than the bootstrap cutoff of 75\%. The isolates USA_CA1.2_BBBQJ and MOR_34-2_ MBDSS were grouped together in clade V. The dissociation of USA_CA1.2_ BBBQJ from the other durum isolates may have resulted from possible spore contamination or DNA sample contamination. The Pakistani isolates with virulence phenotypes CCPSL and FHPSQ were grouped together in clade VI. The common wheat Race1 from the United States (BBBDJ), its variants from Pakistan (BBBDH and CBBDK), and the Mexican race TBDKT were clustered in clade VII. Clades VIII, IX, and X included common wheat M-races. Isolates from Chile with virulence phenotypes MFPNQ, MCDSS, and MBDSS clustered in clade VIII, whereas races MCPSS and MCPSQ from Spain were grouped in clade IX. Clade X contained Spanish races MCTNQ and MHTNQ (Fig. 1).

The isolates within the same clade have similar virulence phenotypes. The number of virulence differences among isolates in each clade based on the $20 \mathrm{Lr}$ genes in Thatcher NILs ranged from zero in clade II to 10 differences in clade VII. On average, only four virulence differences were observed between isolates within the same clade (Fig. 1). The average correlation coefficients between the isolate virulence/avirulence phenotypes were $0.8,1.0,0.8,0.5,0.7,0.6$, $0.7,0.8$, and 0.9 in clade I, clade II, clade III, clade V, clade VI, clade VII, clade VIII, clade IX, and clade X, respectively. This suggests high correlation between the SNP genotypes and virulence phenotypes (Fig. 1).

\section{Discussion}

In the current study, we used the RAD-GBS based on the Ion Torrent platform to genotype $P$. triticina isolates collected from different hosts in several countries and representing several virulence phenotypes. This genotyping method was fast, low-cost, and provided a high density of SNPs compared with previous genotyping methods. There was a relationship between the SNP genotypes and virulence phenotypes, which is expected in clonal populations. This finding is in agreement with several studies, showing moderate correlation between $P$. triticina virulence phenotypes and SSR genotypes (Kolmer 2015; Kolmer et al. 2011, 2013; Ordoñez and Kolmer 2007b, 2009; Ordoñez et al. 2010; Wang et al. 2010a, 2010b). The present study also revealed clear phylogenetic separation between isolates collected from different hosts. In addition, there were more phylogenetic clades observed for the common wheat isolates compared with those observed for tetraploid wheat isolates. This agrees with previous studies that showed limited molecular diversity among isolates from durum wheat and high molecular variation among isolates from common wheat (Kolmer et al. 2019). In contrast to previous phylogenetic trees based on SSRs or AFLPs, a phylogenic tree based on SNPs was supported by high bootstrap values. This indicates that RAD-GBS using Ion Torrent is a reliable tool providing sufficient and robust SNPs for accurate estimation of genetic distance between $P$. triticina isolates. Applying this genotyping method on a larger number of $P$. triticina isolates collected globally will provide a better understanding of the population dynamics and genotypic diversity of $P$. triticina. SNP markers developed from this low-cost and fast genotyping method could also be used for genome-wide association studies to map genes involved with virulence in P. triticina.

The virulence phenotypes of $102 P$. triticina isolates showed distinct differences between durum wheat isolates and common wheat 
isolates. Durum wheat races were avirulent to many $L r$ genes found in Thatcher differentials, indicating that the selection and spread of these races occur only on durum wheat cultivars. The phylogenetic analysis in this study showed that apart from the Ethiopian EEEEE isolates, most of the tetraploid wheat type isolates were related, suggesting a common ancestor. This limited genetic variation of durum wheat specific isolates indicates that most of the $L r$ genes deployed in one region could also be used in other regions worldwide (Ordoñez and Kolmer 2007b). For example, the leaf rust resistance gene Lr.ace-4A in the USDA-NSGC accession PI 192051 conferred resistance against all isolates collected from durum wheat in Tunisia, California, Morocco, and Ethiopia (Aoun et al. 2019).
Six races named BBBQJ, BBBSJ, BBBQK, BBBSQ, BCBQJ, and $C B B Q S$ were identified on durum wheat, indicating virulence to nine known resistance genes ( $L r B, L r 3 a, L r 3 b g, L r 10, L r 14 a, L r 14 b$, $L r 20, L r 26$, and $L r 28$ ) in the Thatcher differential lines. Virulence to some of these $L r$ genes was previously reported among durum wheat isolates. For instance, virulence to $\operatorname{LrB}, \operatorname{Lr} 3 a, \operatorname{Lr} 10, \mathrm{Lr} 14 a$, $L r 14 b, L r 20$, and $L r 28$ was identified in previous studies (Gharbi et al. 2013; Goyeau et al. 2012; Herrera-Foessel et al. 2014b; Huerta-Espino et al. 2009; Kolmer and Acevedo 2016; Ordoñez and Kolmer 2007a; Soleiman et al. 2016). This is the first study to report virulent races to Lr3bg in Tunisia, Lr14a in Morocco, and Lr3bg and Lr28 in Mexico. The high virulence diversity observed

Table 2. Races of Puccinia triticina identified from samples collected from different countries and hosts

\begin{tabular}{|c|c|c|c|c|c|c|c|}
\hline Isolate ID & Country & Location & Host & Variety/line & Race & Virulence to $L r$ genes & GBS $^{\mathbf{a}}$ \\
\hline CHL03-D2 & Chile & & T. aestivum & & MCDSS & $L r 1,3 a, 3 b g, 10,14 a, 14 b, 17,20,26, B$ & $\mathrm{X}$ \\
\hline CHL04-D2 & Chile & & T. aestivum & & MBDSS & $L r 1,3 a, 3 b g, 10,14 a, 14 b, 17,20, B$ & $\mathrm{X}$ \\
\hline CHL33-D2 & Chile & & T. aestivum & & MFPNQ & $\mathrm{Lr} 1,3 a, 3 \mathrm{ka}, 3 \mathrm{bg}, 14 a, 14 b, 17,24,26,30, B$ & $\mathrm{X}$ \\
\hline CHL02-D1 & Chile & & T. turgidum & & BBBSJ & $\operatorname{Lr} 10,14 a, 14 b, 20, B$ & $\mathrm{X}$ \\
\hline CHL14-1 & Chile & & T. turgidum & & BBBQJ & $\operatorname{Lr} 10,14 b, 20, B$ & $\mathrm{X}$ \\
\hline $52-1^{\mathrm{b}}$ & Ethiopia & DZARC- Bishoftu & T. aestivum & B21 & MBJS- & $L r 1,3 a, 10,11,14 a, 17, B$ & \\
\hline $45-6^{b}$ & Ethiopia & DZARC- Bishoftu & T. dicoccum & & EEEEE & - & \\
\hline $47-2^{b}$ & Ethiopia & DZARC- Bishoftu & T. dicoccum & & EEEEE & - & \\
\hline $48-3^{b}$ & Ethiopia & DZARC- Bishoftu & T. dicoccum & & EEEEE & - & $\mathrm{X}$ \\
\hline $49-1^{\mathrm{b}}$ & Ethiopia & DZARC- Bishoftu & T. dicoccum & & EEEEE & - & \\
\hline $49-2$ & Ethiopia & DZARC- Bishoftu & T. dicoccum & & EEEEE & - & \\
\hline $50-1^{b}$ & Ethiopia & DZARC- Bishoftu & T. dicoccum & & EEEEE & - & \\
\hline $50-4^{b}$ & Ethiopia & DZARC- Bishoftu & T. dicoccum & & EEEEE & - & $\mathrm{X}$ \\
\hline $57-2$ & Ethiopia & DZARC- Bishoftu & T. turgidum & $182 / S r 30$ & EEEEE & - & \\
\hline $58-1^{\mathrm{b}}$ & Ethiopia & DZARC- Bishoftu & T. turgidum & Rusty & EEEEE & - & \\
\hline $62-2^{b}$ & Ethiopia & DZARC- Bishoftu & T. turgidum & PI 272553 (NSGC) & EEEEE & - & $X^{c}$ \\
\hline $63-1$ & Ethiopia & DZARC- Bishoftu & T. turgidum & PI 387346 (NSGC) & EEEEE & - & \\
\hline $63-2$ & Ethiopia & DZARC- Bishoftu & T. turgidum & PI 387346 (NSGC) & EEEEE & - & \\
\hline $63-3$ & Ethiopia & DZARC- Bishoftu & T. turgidum & PI 387346 (NSGC) & EEEEE & - & $\mathrm{X}^{\mathrm{c}}$ \\
\hline $64-1^{b}$ & Ethiopia & DZARC- Bishoftu & T. turgidum & PI 478427 (NSGC) & EEEEE & - & \\
\hline $64-3^{b}$ & Ethiopia & DZARC- Bishoftu & T. turgidum & PI 478427 (NSGC) & EEEEE & - & \\
\hline $65-2$ & Ethiopia & DZARC- Bishoftu & T. turgidum & PI 298547 (NSGC) & EEEEE & - & \\
\hline 12 & Mexico & & T. aestivum & & TBDKT & $\operatorname{Lr} 1,2 a, 2 c, 3 a, 3 b g, 10,14 a, 14 b, 17,18,20,28$ & $\mathrm{X}$ \\
\hline 17 & Mexico & & T. aestivum & & CBDSS & $L r 3 a, 3 b g, 10,14 a, 14 b, 17,18,20,28, B$ & $X^{c}$ \\
\hline 13 & Mexico & & T. turgidum & & BBBQJ & $\operatorname{Lr} 10,14 b, 20, B$ & \\
\hline 10 & Mexico & & T. turgidum & & $\mathrm{BCBQJ}$ & $\operatorname{Lr} 10,14 b, 20,26, B$ & \\
\hline 11 & Mexico & & T. turgidum & & CBBQS & $L r 3 a, 10,3 b g, 14 b, 20, B$ & $\mathrm{X}$ \\
\hline 14 & Mexico & & T. turgidum & & BBBQK & $\operatorname{Lr} 10,14 b, 20,28, B$ & $\mathrm{X}$ \\
\hline 15 & Mexico & & T. turgidum & & BBBQJ & $\operatorname{Lr} 10,14 b, 20, B$ & \\
\hline $28-1$ & Morocco & Zemamra & T. aestivum & & MCDSS & $L r 1,3 a, 3 b g, 10,14 a, 14 b, 17,20,26, B$ & \\
\hline $28-2$ & Morocco & Zemamra & T. aestivum & & MCDSS & $L r 1,3 a, 3 b g, 10,14 a, 14 b, 17,20,26, B$ & \\
\hline $29-1$ & Morocco & Zemamra & T. aestivum & & MCDSS & $L r 1,3 a, 3 b g, 10,14 a, 14 b, 17,20,26, B$ & \\
\hline $29-2$ & Morocco & Zemamra & T. aestivum & & MCDSS & $L r 1,3 a, 3 b g, 10,14 a, 14 b, 17,20,26, B$ & \\
\hline $30-1^{\mathrm{b}}$ & Morocco & Zemamra & T. aestivum & & BBBQJ & $\operatorname{Lr} 10,14 b, 20, B$ & \\
\hline $30-2$ & Morocco & Zemamra & T. aestivum & & BBBQJ & $\operatorname{Lr} 10,14 b, 20, B$ & \\
\hline $30-3$ & Morocco & Zemamra & T. aestivum & & BBBQJ & $\operatorname{Lr} 10,14 b, 20, B$ & $\mathrm{X}$ \\
\hline $34-2$ & Morocco & Jemaa-Shaam & T. aestivum & & MBDSS & $L r 1,3 a, 3 b g, 10,14 a, 14 b, 17,20, B$ & $\mathrm{X}$ \\
\hline $35-1$ & Morocco & Jemaa-Shaam & T. aestivum & & FBBPQ & $L r 2 c, 3 a, 3 b g, 14 a, 14 b, B$ & \\
\hline $41-1$ & Morocco & & T. aestivum & Taza (seisii) & MCDST & $L r 1,3 a, 3 b g, 10,14 a, 14 b, 17,20,26,28, B$ & $\mathrm{X}^{\mathrm{c}}$ \\
\hline $43-1^{b}$ & Morocco & & T. aestivum & Meknes & MCDSS & $L r 1,3 a, 3 b g, 10,14 a, 14 b, 17,20,26, B$ & \\
\hline $43-3$ & Morocco & & T. aestivum & Meknes & MCDSS & $L r 1,3 a, 3 b g, 10,14 a, 14 b, 17,20,26, B$ & $X^{c}$ \\
\hline $44-1^{\mathrm{b}}$ & Morocco & & T. aestivum & Seiz & MCDSS & $L r 1,3 a, 3 b g, 10,14 a, 14 b, 17,20,26, B$ & \\
\hline $25-1$ & Morocco & Zemamra & T. turgidum & MERZAV & BBBQJ & $\operatorname{Lr} 10,14 b, 20, B$ & \\
\hline $25-2^{b}$ & Morocco & Zemamra & T. turgidum & MERZAV & BBBQJ & $\operatorname{Lr} 10,14 b, 20, B$ & \\
\hline $25-6^{b}$ & Morocco & Zemamra & T. turgidum & MERZAV & BBBQJ & $\operatorname{Lr} 10,14 b, 20, B$ & \\
\hline $26-1$ & Morocco & Zemamra & T. turgidum & & BBBQJ & $\operatorname{Lr} 10,14 b, 20, B$ & $X^{c}$ \\
\hline $26-2$ & Morocco & Zemamra & T. turgidum & & BBBQJ & $\operatorname{Lr} 10,14 b, 20, B$ & \\
\hline $26-3$ & Morocco & Zemamra & T. turgidum & & BBBSJ & $\operatorname{Lr} 10,14 a, 14 b, 20, B$ & \\
\hline \multicolumn{8}{|c|}{ (Continued on next page) } \\
\hline
\end{tabular}

\footnotetext{
a The samples with symbol " $\mathrm{X}$ " were genotyped using restriction-associated DNA genotyping-by-sequencing (GBS).

b Isolates phenotyped at the North Dakota Agricultural Experiment Station Greenhouse Complex, Fargo, ND; the rest of the isolates were phenotyped at the USDA-ARS Cereal Disease Laboratory, St. Paul, MN.

${ }^{\mathrm{c}}$ Isolates removed from analysis because of missing genotypic data points $>10 \%$.
} 
in fields in Mexico is probably due to the extensive planting of durum wheat in the country and selection pressure caused by the sequential utilization of a number of $L r$ genes in the CIMMYT durum breeding lines and cultivars. Recent leaf rust outbreaks on durum wheat have been recorded in Mexico over the past decades (Herrera-Foessel et al. 2005, 2007, 2008a, 2008b, 2014a), due the appearance of races with virulence to the newly deployed leaf rust resistance genes in the durum cultivars. Utilization of more complex leaf rust resistance such as stacking of multiple genes and use of non-race-specific genes in the newly released cultivars can reduce the chance of future outbreaks and potentially slow down the selection process for new virulences (Ayliffe et al. 2008).
Isolates with virulence to tetraploid wheat designated as race EEEEE types were only observed in Ethiopia. The phylogenetic analysis based on SNP genotypes distinguished the EEEEE isolates from all other isolates. Similar observations were made in previous studies based on virulence phenotypes and SSR genotypes (HuertaEspino and Roelfs 1992; Kolmer and Acevedo 2016; Ordoñez and Kolmer 2007a, 2007b). These isolates have most likely evolved and been maintained in Ethiopia due to the high diversity of tetraploid wheat population grown in the country (Kolmer and Acevedo 2016). In this study, we observed small genotypic variation between EEEEE isolates, which was similar to results obtained by whole genome sequencing of a number of EEEEE isolates (J. A. Kolmer,

Table 2. (Continued from previous page)

\begin{tabular}{|c|c|c|c|c|c|c|c|}
\hline Isolate ID & Country & Location & Host & Variety/line & Race & Virulence to $L r$ genes & GBS $^{\mathbf{a}}$ \\
\hline $27-1$ & Morocco & Zemamra & T. turgidum & CARIOCA & BBBQJ & $\operatorname{Lr} 10,14 b, 20, B$ & \\
\hline $27-2^{b}$ & Morocco & Zemamra & T. turgidum & CARIOCA & BBBQJ & $\operatorname{Lr} 10,14 b, 20, B$ & $X^{c}$ \\
\hline $32-2$ & Morocco & Jemaa-Shaam & T. turgidum & & BBBSJ & $\operatorname{Lr} 10,14 a, 14 b, 20, B$ & \\
\hline $33-1^{\mathrm{b}}$ & Morocco & Jemaa-Shaam & T. turgidum & & BBBSJ & $\operatorname{Lr} 10,14 a, 14 b, 20, B$ & $X^{c}$ \\
\hline $36-1^{\mathrm{b}}$ & Morocco & Jemaa-Shaam & T. turgidum & & BBBSJ & $\operatorname{Lr} 10,14 a, 14 b, 20, B$ & \\
\hline $36-3$ & Morocco & Jemaa-Shaam & T. turgidum & & BBBQJ & $\operatorname{Lr} 10,14 b, 20, B$ & \\
\hline $37-2^{\mathrm{b}}$ & Morocco & Rabat & T. turgidum & RL7075 & BBBQJ & $\operatorname{Lr} 10,14 b, 20, B$ & \\
\hline $38-1$ & Morocco & Rabat & T. turgidum & Cali (A33File1) & BBBQJ & $\operatorname{Lr} 10,14 b, 20, B$ & \\
\hline $38-2$ & Morocco & Rabat & T. turgidum & Cali (A33File1) & BBBQJ & $\operatorname{Lr} 10,14 b, 20, B$ & $\mathrm{X}$ \\
\hline $38-3$ & Morocco & Rabat & T. turgidum & Cali (A33File1) & BBBQJ & $\operatorname{Lr} 10,14 b, 20, B$ & \\
\hline $39-9$ & Morocco & Marchouch & T. turgidum & Kristal/Sebatel \#7 & BBBQJ & $\operatorname{Lr} 10,14 b, 20, B$ & \\
\hline $40-1$ & Morocco & Marchouch & T. turgidum & Kristal & BBBQJ & $\operatorname{Lr} 10,14 b, 20, B$ & \\
\hline 13PAK15-1 & Pakistan & & T. aestivum & & FHPSQ & Lr2c, 3a, 3ka, 3bg, 10, 14a, 14b, 16, 17, 26, 30, B & $\mathrm{X}$ \\
\hline 13PAK17-1 & Pakistan & & T. aestivum & & CCPSL & Lr3a $, 3 \mathrm{ka}, 3 \mathrm{bg}, 10,14 a, 17,26,30, B$ & $\mathrm{X}$ \\
\hline 14PAK1-2 & Pakistan & & T. aestivum & & $\mathrm{BBBDH}$ & $\operatorname{Lr} 14 a, 14 b, 28$ & $\mathrm{X}$ \\
\hline 14PAK1-3 & Pakistan & & T. aestivum & & $\mathrm{BBBDH}$ & $\operatorname{Lr} 14 a, 14 b, 28$ & $X$ \\
\hline 14PAK1-4 & Pakistan & & T. aestivum & & CBBDK & $L r 3 a, 14 a, 14 b, 20,28$ & $\mathrm{X}$ \\
\hline $6-1$ & Spain & Jerez de la Frontera & Triticale & & FBBNQ & $L r 2 c, 3 a, 3 b g, 14 a, 14 b, B$ & $\mathrm{X}$ \\
\hline $6-2$ & Spain & Jerez de la Frontera & Triticale & & FBBPQ & $L r 2 c, 3 a, 3 b g, 14 a, 14 b, 18, B$ & $\mathrm{X}$ \\
\hline $6-3$ & Spain & Jerez de la Frontera & Triticale & & CBGNQ & $L r 3 a, 3 b g, 11,14 a, 14 b B$ & $\mathrm{X}$ \\
\hline $6-4$ & Spain & Jerez de la Frontera & Triticale & & FBBPQ & $L r 2 c, 3 a, 3 b g, 14 a, 14 b, B$ & \\
\hline $2-1$ & Spain & Learza (Navarra) & T. aestivum & NSA11-8606 & MCPSS & $L r 1,3 a, 14 a, 18,26, B$ & $\mathrm{X}$ \\
\hline $2-2$ & Spain & Learza (Navarra) & T. aestivum & NSA11-8606 & MCPSS & $\operatorname{Lr} 1,3 a, 14 a, 18,26, B$ & \\
\hline $2-3$ & Spain & Learza (Navarra) & T. aestivum & NSA11-8606 & MCPSS & $L r 1,3 a, 14 a, 18,26, B$ & \\
\hline $3-1$ & Spain & Huesca & T. aestivum & L6W14-8082 & MCDSQ & $L r 1,3 a, 3 b g, 10,14 a, 14 b, 17,26, B$ & \\
\hline $3-2$ & Spain & Huesca & T. aestivum & L6W14-8082 & MCDSQ & $L r 1,3 a, 3 b g, 10,14 a, 14 b, 17,26, B$ & \\
\hline $7-1$ & Spain & Huesca & T. aestivum & $12-15-1515$ & MCTNQ & $L r 1,3 a, 3 k a, 3 b g, 11,14 a, 14 b, 17,26,30, B$ & $\mathrm{X}$ \\
\hline $7-2$ & Spain & Huesca & T. aestivum & $12-15-1515$ & MHTNQ & $L r 1,3 a, 3 k a, 3 b g, 11,14 a, 14 b, 16,17,26,30, B$ & $\mathrm{X}$ \\
\hline $7-3$ & Spain & Huesca & T. aestivum & $12-15-1515$ & MCTNQ & $\mathrm{Lr} 1,3 a, 3 \mathrm{ka}, 3 \mathrm{bg}, 11,14 a, 14 b, 17,26,30, B$ & $\mathrm{X}$ \\
\hline $8-1$ & Spain & Peralta/Navarra & T. aestivum & 125B0254-B & MCPSS & $L r 1,3 a, 3 k a, 3 b g, 10,14 a, 14 b, 17,20,26,30, B$ & \\
\hline $8-2$ & Spain & Peralta/Navarra & T. aestivum & 125B0254-B & MCPSS & $L r 1,3 a, 3 k a, 3 b g, 10,14 a, 14 b, 17,20,26,30, B$ & \\
\hline $9-1$ & Spain & & T. aestivum & Garcia & MHPSQ & $L r 1,3 a, 3 k a, 3 b g, 10,14 a, 14 b, 16,17,26, B$ & \\
\hline $9-2$ & Spain & & T. aestivum & Garcia & MCPSQ & $L r 1,3 a, 3 k a, 3 b g, 10,14 a, 14 b, 17,26, B$ & $\mathrm{X}$ \\
\hline $4-1$ & Spain & Coril (Cadiz) & T. turgidum & Don Jaime $L r 14 a$ & BBBSJ & $L r 10,14 a, 14 b, 20, B$ & $X^{c}$ \\
\hline $4-2$ & Spain & Coril (Cadiz) & T. turgidum & Don Jaime $L r 14 a$ & BBBSJ & $\operatorname{Lr} 10,14 a, 14 b, 20, B$ & \\
\hline $4-3$ & Spain & Coril (Cadiz) & T. turgidum & Don Jaime $L r 14 a$ & BBBSJ & $\operatorname{Lr} 10,14 a, 14 b, 20, B$ & \\
\hline $5-1$ & Spain & Coril (Cadiz) & T. turgidum & Gallareta $\operatorname{Lr} 72$ & BBBSJ & $L r 10,14 a, 14 b, 20, B$ & \\
\hline $5-2$ & Spain & Coril (Cadiz) & T. turgidum & Gallareta $\operatorname{Lr} 72$ & BBBSJ & $\operatorname{Lr} 10,14 a, 14 b, 20, B$ & $X^{c}$ \\
\hline $19-1$ & Tunisia & & Triticale & & FCBPQ & $\operatorname{Lr} 2 c, 3 a, 3 b g, 14 a, 14 b, 26, B$ & $\mathrm{X}$ \\
\hline $18-1$ & Tunisia & Beja exp. station & T. aestivum & UNK & BBBSQ & $\operatorname{LrB}, 3 b g, 10,14 a, 14 b$ & $\mathrm{X}$ \\
\hline $18-2$ & Tunisia & Beja exp. station & T. aestivum & UNK & BBBSJ & $\operatorname{Lr} 10,14 a, 14 b, 20, B$ & \\
\hline $20-1$ & Tunisia & Grombalia & T. turgidum & Maali & BBBSJ & $\operatorname{Lr} 10,14 a, 14 b, 20, B$ & \\
\hline $20-2$ & Tunisia & Grombalia & T. turgidum & Maali & BBBSJ & $\operatorname{Lr} 10,14 a, 14 b, 20, B$ & \\
\hline $20-4$ & Tunisia & Grombalia & T. turgidum & Maali & BBBSJ & $\operatorname{Lr} 10,14 a, 14 b, 20, B$ & $\mathrm{X}^{\mathrm{c}}$ \\
\hline $22-2$ & Tunisia & Jendouba & T. turgidum & Maali & BBBSJ & $\operatorname{Lr} 10,14 a, 14 b, 20, B$ & $\mathrm{X}^{\mathrm{c}}$ \\
\hline $22-3$ & Tunisia & Beja exp. station & T. turgidum & Maali & BBBSJ & $\operatorname{Lr} 10,14 a, 14 b, 20, B$ & \\
\hline $23-1$ & Tunisia & Mateur & T. turgidum & Nasr & BBBSJ & $\operatorname{Lr} 10,14 a, 14 b, 20, B$ & \\
\hline $23-2$ & Tunisia & Mateur & T. turgidum & Nasr & BBBSJ & $\operatorname{Lr} 10,14 a, 14 b, 20, B$ & \\
\hline $23-3$ & Tunisia & Mateur & T. turgidum & Nasr & BBBSJ & $\operatorname{Lr} 10,14 a, 14 b, 20, B$ & \\
\hline $24-1$ & Tunisia & INRAT & T. turgidum & & BBBQJ & $\operatorname{Lr} 10,14 b, 20, B$ & $\mathrm{X}^{\mathrm{c}}$ \\
\hline $24-2$ & Tunisia & INRAT & T. turgidum & & BBBSQ & $\operatorname{LrB}, 3 b g, 10,14 a, 14 b$ & $\mathrm{X}^{\mathrm{c}}$ \\
\hline Race1 & U.S.A. & & T. aestivum & & BBBDJ & $\operatorname{Lr14a}, 14 b, 20$ & $\mathrm{X}$ \\
\hline CA1.2 & U.S.A. & California & T. turgidum & & BBBQJ & $\operatorname{Lr} 10,14 b, 20, B$ & $\mathrm{X}$ \\
\hline
\end{tabular}


unpublished data). Coalescence and phylogenetic analysis indicated that the EEEEE isolates were the first form of $P$. triticina to have virulence to either tetraploid or hexaploid wheat (Liu et al. 2014). The unique wheat population in Ethiopia that includes landrace durum and emmer wheat cultivars may have selected this particular phenotype (Kolmer and Acevedo 2016). We identified five virulence phenotypes among seven tested EEEEE isolates based on durum differentials. This differential set can be useful to further study

Table 3. Virulence/avirulence profile of seven Ethiopian EEEEE isolates tested on durum wheat accessions ${ }^{\mathrm{a}}$

\begin{tabular}{|c|c|c|c|c|c|c|c|c|c|}
\hline Line & Type & Country & $\begin{array}{c}\text { 49-1:b } \\
\text { EEEEE }\end{array}$ & $\begin{array}{c}\text { 50-4: } \\
\text { EEEEE }\end{array}$ & $\begin{array}{c}\text { 57-2: } \\
\text { EEEEE }\end{array}$ & $\begin{array}{c}\text { 63-1: } \\
\text { EEEEE }\end{array}$ & $\begin{array}{c}\text { 63-3: } \\
\text { EEEEE }\end{array}$ & $\begin{array}{c}\text { 64-1: } \\
\text { EEEEE }\end{array}$ & $\begin{array}{c}\text { 65-2: } \\
\text { EEEEE }\end{array}$ \\
\hline PI 45442 & Cultivated & South Africa & 0 & $; 13$ & 0 & ; & $; 1$ & ;1- & $; 1$ \\
\hline PI 192051 & Landrace & Portugal & 0 & $; 1$ & ;1- & 0 & 0 & 0 & 0 \\
\hline PI 195693 & Landrace & Ethiopia & $; 1$ & $1+3$ & ;1- & $; 1$ & $; 1$ & $; 1-$ & $; 1$ \\
\hline PI $209274^{\mathrm{c}}$ & Breeding line & Australia & 3 & 3 & $; 1+$ & 3 & 3 & 3 & 3 \\
\hline PI $244061^{\mathrm{c}}$ & Landrace & Yemen & . & 31 & 0 & ; & ; & ; & 0 \\
\hline PI $278379^{c}$ & Landrace & Malta & 1 & 3 & $2-$ & 3 & 3 & . & $; 1$ \\
\hline PI 313096 & Landrace & Cyprus & 0 & $; 1$ & $; 1$ & 0 & 0 & $1-$ & 0 \\
\hline PI 324928 & Breeding line & Argentina & 0 & ;13 & $1-$ & $; 1$ & ; & ;13- & ;1- \\
\hline PI 342647 & Cultivated & Lebanon & 0 & $; 1+$ & ;1- & ; & 0 & ; & 0 \\
\hline PI $387263^{c}$ & Landrace & Ethiopia & $1+$ & 3 & $; 1$ & 3 & 3 & $3-$ & $1+$ \\
\hline PI 519832 & Cultivar & Lebanon & 0 & ;1 & ;1- & 1 & $; 1$ & 0 & ;1 \\
\hline PI 534304 & Landrace & Ethiopia & 0 & ;13 & 0 & ; & 0 & 0 & 0 \\
\hline Divide & Cultivar & U.S.A. & $2+3-$ & 13 & 1 & $; 1$ & $1+$ & $2+3$ & ;1 \\
\hline Rusty & Line & U.S.A. & 3 & 3 & $3-$ & 3 & . & 3 & 3 \\
\hline Capelli & Cultivar & Italy & ;1- & $; 1+$ & $; 1$ & $; 1$ & 1 & ;1- & 1 \\
\hline Mindum $^{c}$ & Cultivar & U.S.A. & 3 & $; 1$ & 1 & $; 1$ & ;1 & 1 & ;1- \\
\hline Creso & Cultivar & Italy & 0 & ;1- & ;1- & ; & 0 & ;1- & 0 \\
\hline Llareta INIA $^{\mathrm{c}}$ & Cultivar & Mexico & 3 & $3+$ & 1 & $; 13$ & $; 13$ & $1+$ & ;13 \\
\hline Camayo $^{\mathrm{c}}$ & Cultivar & Mexico & ;1- & 3 & 0 & 1 & $; 1$ & ;1- & ;1 \\
\hline Jupare C2001 & Cultivar & Mexico & ;1- & ; & 1 & $; 1$ & ;1- & $; 1$ & ;1- \\
\hline Mexicali $75^{c}$ & Cultivar & Mexico & 3 & 3 & $; 1$ & 3 & $3-$ & $3-$ & 2 \\
\hline Alred & Line & Mexico & 3 & 4 & 3 & 3 & $32+$ & 3 & $32+$ \\
\hline Russello S.G.7c & Cultivar & Italy & 3 & 3 & 2 & 3 & 3 & 3 & 3 \\
\hline Thatcher & Cultivar & U.S.A. & $; 1$ & ;1- & $2+$ & ;1- & $1-$ & $; 1$ & 2 \\
\hline
\end{tabular}

a All the accessions are Triticum turgidum spp. durum, except Thatcher is T. aestivum (resistant check).

${ }^{\mathrm{b}}$ Isolate number.

${ }^{c}$ Accessions that differentiated between the Ethiopian EEEEE isolates.

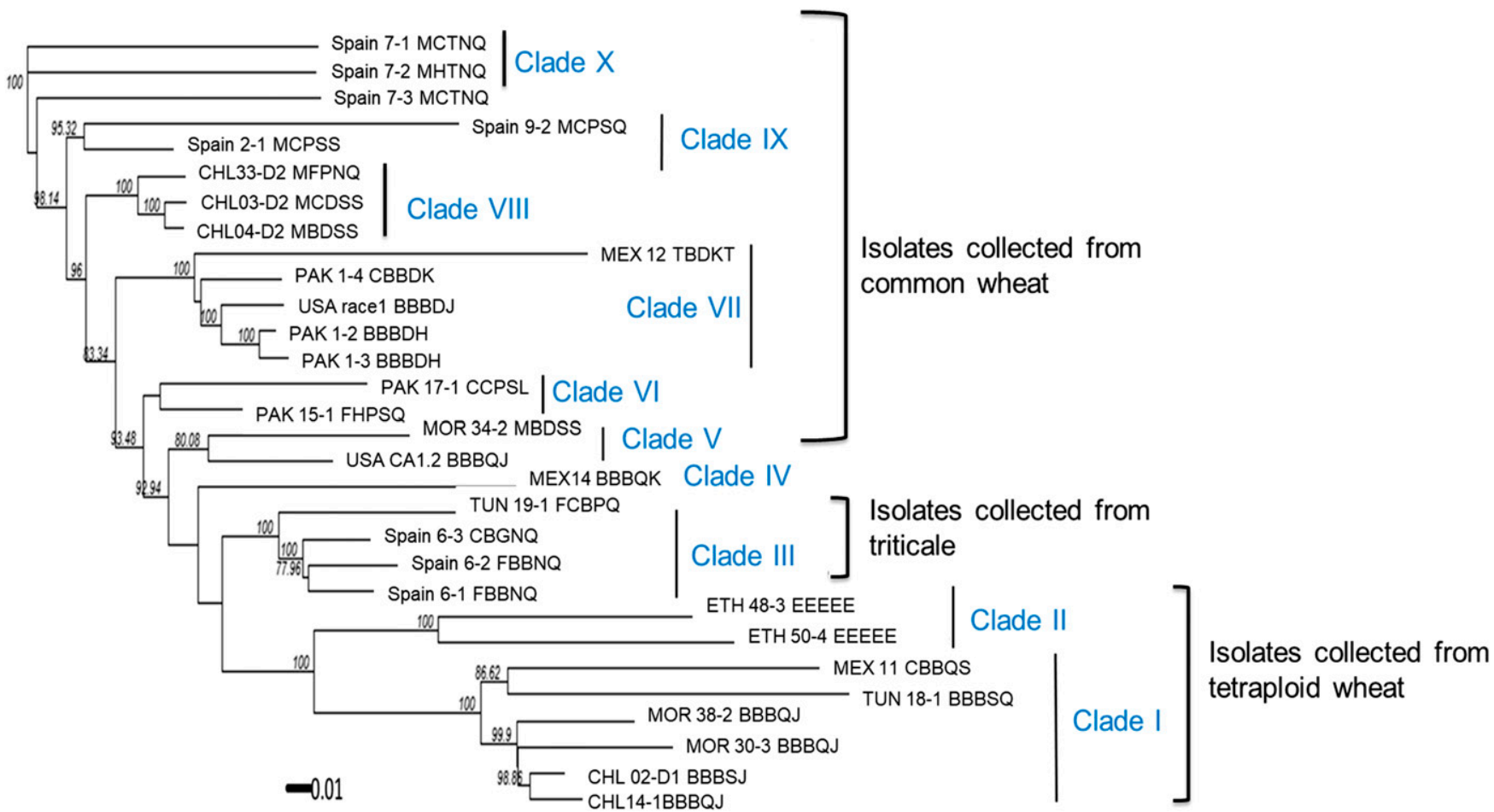

Fig. 1. Neighbor-joining phylogenetic tree of 30 Puccinia triticina isolates collected on durum wheat, emmer wheat, common wheat, and triticale, based on Nei's genetic distances calculated using 2,125 single nucleotide polymorphism markers. Isolate name was based on country $(\mathrm{USA}=\mathrm{United} \mathrm{States}, \mathrm{CHL}=\mathrm{Chile}, \mathrm{MEX}=\mathrm{Mexico}, \mathrm{PAK}=\mathrm{Pakistan}, \mathrm{MOR}=$ Morocco, TUN = Tunisia, and ETH = Ethiopia), collection number, and race-based virulence phenotypes on Thatcher differentials. Numbers along the nodes are bootstrap values $>75 \%$ in 5,000 replicates. 
virulence diversity in durum wheat type isolates. Previously, a differential set adapted for $P$. triticina isolates collected on durum wheat was implemented by Goyeau et al. (2012). With the increased susceptibility of durum to leaf rust worldwide, there is a need to develop a standardized differential set adequate to assess virulence diversity in the durum type $P$. triticina population.

In summary, the current study is the first of its kind in using RADGBS to study the genetic variation in P. triticina. The abundant and robust SNPs that are distributed across the genome provided higher levels of support for estimating the genetic distances between isolates. There was a clear separation between isolates from different hosts, with higher genotypic diversity in isolates collected from common wheat compared with that observed in isolates collected from tetraploid wheat. In contrast to common wheat races, virulence to $L r$ genes LrB, Lr3a, Lr3bg, Lr10, Lr14a, Lr14b, Lr20, Lr26, and Lr28 was observed among the durum wheat races. The EEEEE isolates collected from tetraploid wheat in Ethiopia showed a unique virulence phenotype and SNP genotype. Durum differentials were developed to identify the virulence diversity between the Ethiopian EEEEE isolates.

\section{Acknowledgments}

We thank Julio Huerta-Espino from CIMMYT for kindly providing $P$. triticina isolates from Mexico. We also thank Mohamed Salah Gharbi, Filippo Bassi, and Ignacio Solis for providing durum wheat leaf samples infected with $P$. triticina from Tunisia, Morocco, and Spain, respectively. We thank Jerry Johnson, Amy Fox, and Kun Xiao (USDA-ARS CDL) for excellent technical assistance.

\section{Literature Cited}

Adhikari, L., and Missaoui, A. M. 2019. Quantitative trait loci mapping of leaf rust resistance in tetraploid alfalfa. Physiol. Mol. Plant Pathol. 106:238-245.

Aoun, M., Breiland, M., Turner, M. K., Loladze, A., Chao, S., Xu, S. S., Ammar, K., Anderson, J. A., Kolmer, J. A., and Acevedo, M. 2016. Genome-wide association mapping of leaf rust response in a durum wheat worldwide germplasm collection. Plant Gene 9. doi: 10.3835/plantgenome2016.01.0008.

Aoun, M., Kolmer, J. A., Rouse, M., Elias, E., Breiland, M., Worku, D. B., Chao, S., and Acevedo, M. 2019. Mapping of novel leaf rust and stem rust resistance genes in the Portuguese durum wheat landrace PI 192051. G3-Genes Genom. Genet. 9:1-13

Aoun, M., Kolmer, J. A., Rouse, M. N., Chao, S., Bulbula, W. D., Elias, E. M., and Acevedo, M. 2017. Inheritance and bulked segregant analysis of leaf rust and stem rust resistance in durum wheat genotypes. Phytopathology 107:1496-1506.

Ayliffe, M., Singh, R., and Lagudah, E. 2008. Durable resistance to wheat stem rust needed. Curr. Opin. Plant Biol. 11:187-192.

Carlsen, S. A., Neupane, A., Wyatt, N. A., Richards, J. K., Faris, J. D., Xu, S. S., Brueggeman, R. S., and Friesen, T. L. 2017. Characterizing the Pyrenophora teres f. maculata-barley interaction using pathogen genetics. G3 Genes Genom. Genet. 7:2615-2626.

Chester, K. S. 1946. The Nature and Prevention of the Cereal Rusts as Exemplified in the Leaf Rust of Wheat. Chronica Botanica, Waltham, MA.

Danecek, P., Auton, A., Abecasis, G., Albers, C. A., Banks, E., DePristo, M. A., Handsaker, R. E., Lunter, G., Marth, G. T., Sherry, S. T., and McVean, G. 2011. The variant call format and VCFtools. Bioinformatics 27:2156-2158.

DePristo, M. A., Banks, E., Poplin, R., Garimella, K. V., Maguire, J. R., Hartl, C., Philippakis, A. A., Del Angel, G., Rivas, M. A., Hanna, M., and McKenna, A. 2011. A framework for variation discovery and genotyping using nextgeneration DNA sequencing data. Nat. Genet. 43:491-498.

Duan, X., Enjalbert, J., Vautrin, D., Solignac, M., and Giraud, T. 2003. Isolation of 12 microsatellite loci, using an enrichment protocol, in the phytopathogenic fungus Puccinia triticina. Mol. Ecol. Notes 3:65-67.

Elshire, R. J., Glaubitz, J. C., Sun, Q., Poland, J. A., Kawamoto, K., Buckler, E. S., and Mitchell, S. E. 2011. A robust, simple genotyping-by-sequencing (GBS) approach for high diversity species. PLoS One 6:e19379.

Gao, Y., Liu, Z., Faris, J. D., Richards, J., Brueggeman, R. S., Li, X., Oliver, R. P., McDonald, B. A., and Friesen, T. L. 2016. Validation of genome-wide association studies as a tool to identify virulence factors in Parastagonospora nodorum. Phytopathology 106:1177-1185.

Gharbi, M. S., Ammar, K., Berrias, S., Karboul, K., and Manel, A. 2013. Mitigating the threat of leaf rust to durum yield stability in new Septoria tritici blotch resistant germplasm in Tunisia. Borlaug Global Rust Initiative Tech. Workshop, New Delhi, India, 19-22 Aug. 2013.

Goyeau, H., Berder, J., Czerepak, C., Gautier, A., Lanen, C., and Lannou, C. 2012. Low diversity and fast evolution in the population of Puccinia triticina causing durum wheat leaf rust in France from 1999 to 2009, as revealed by an adapted differential set. Plant Pathol. 61:761-772.

Goyeau, H., Park, R., Schaeffer, B., and Lannou, C. 2006. Distribution of pathotypes with regard to host cultivars in French wheat leaf rust populations. Phytopathology 96:264-273.
Herrera-Foessel, S., Singh, R., Huerta-Espino, J., William, H., Garcia, V., Djurle, A., and Yuen, J. 2008b. Identification and molecular characterization of leaf rust resistance gene LrI4a in durum wheat. Plant Dis. 92:469-473.

Herrera-Foessel, S., Singh, R. P., Huerta-Espino, J., William, H., Rosewarne, G., Djurle, A., and Yuen, J. 2007. Identification and mapping of Lr3a and a linked leaf rust resistance gene in durum wheat. Crop Sci. 47:1459-1466.

Herrera-Foessel, S. A., Huerta-Espino, J., Calvo-Salazar, V., Lan, C. X., and Singh, R. P. 2014a. Lr72 confers resistance to leaf rust in durum wheat cultivar Atil C2000. Plant Dis. 98:631-635.

Herrera-Foessel, S. A., Singh, R. P., Huerta-Espino, J., Calvo-Salazar, V., Lan, C. Basnet, B. R., and Lagudah, E. S. 2014b. Achieving sustainable leaf rust control in durum wheat: What have we learnt and how to move forward. Borlaug Global Rust Initiative Workshop, Cd. Obregon, Mexico, March 2014.

Herrera-Foessel, S. A., Singh, R. P., Huerta-Espino, J., William, H. M., Djurle, A., and Yuen, J. 2008a. Molecular mapping of a leaf rust resistance gene on the short arm of chromosome 6B of durum wheat. Plant Dis. 92:1650-1654.

Herrera-Foessel, S. A., Singh, R. P., Huerta-Espino, J., Yuen, J., and Djurle, A 2005. New genes for leaf rust resistance in CIMMYT durum wheats. Plant Dis. 89:809-814.

Huerta-Espino, J., and Roelfs, A. 1992. Leaf rust on durum wheats. Vortr Pflanzenzuchtg. 24:100-102.

Huerta-Espino, J., Singh, R., and Perez-Lopez, J. 2009. Phenotypic variation among leaf rust isolates from durum wheat in Northwestern Mexico. Page 29 in: Proc. 12th Int. Cereal Rusts Powdery Mildews Conf.

Jombart, T. 2008. adegenet: An R package for the multivariate analysis of genetic markers. Bioinformatics 24:1403-1405.

Kamvar, Z. N., Tabima, J. F., and Grünwald, N. J. 2014. Poppr: An R package for genetic analysis of populations with clonal, partially clonal, and/or sexual reproduction. PeerJ 2:e281

Kolmer, J., Ordonez, M. E., German, S. E., Morgunov, A., Pretorius, Z. A., Visser, B., Goyeau, H., Anikster, Y., and Acevedo, M. 2019. Multilocus genotypes of the wheat leaf rust fungus Puccinia triticina in worldwide regions indicate past and current long distance migration. Phytopathology 109:1453-1463.

Kolmer, J. A. 2001. Molecular polymorphism and virulence phenotypes of the wheat leaf rust fungus Puccinia triticina in Canada. Can. J. Bot. 79:917-926.

Kolmer, J. A. 2013. Leaf rust of wheat: Pathogen biology, variation and host resistance. Forests 4:70-84

Kolmer, J. A. 2015. Collections of Puccinia triticina in different provinces of China are highly related for virulence and molecular genotype. Phytopathology 105:700-706.

Kolmer, J. A., and Acevedo, M. 2016. Genetically divergent types of the wheat leaf fungus Puccinia triticina in Ethiopia, a center of tetraploid wheat diversity. Phytopathology 106:380-385.

Kolmer, J. A., Hanzalova, A., Goyeau, H., Bayles, R., and Morgounov, A. 2013 Genetic differentiation of the wheat leaf rust fungus Puccinia triticina in Europe. Plant Pathol. 62:21-31.

Kolmer, J. A., and Hughes, M. E. 2016. Physiologic specialization of Puccinia triticina on wheat in the United States in 2014. Plant Dis. 100:1768-1773.

Kolmer, J. A., and Liu, J. Q. 2000. Virulence and molecular polymorphism in international collections of the wheat leaf rust fungus Puccinia triticina. Phytopathology 90:427-436.

Kolmer, J. A., Liu, J. Q., and Sies, M. 1995. Virulence and molecular polymorphism in Puccinia recondita f. sp. tritici in Canada. Phytopathology 85:276-285.

Kolmer, J. A., Ordoñez, M. E., Manisterski, J., and Anikster, Y. 2011. Genetic differentiation of Puccinia triticina populations in the Middle East and genetic similarity with populations in Central Asia. Phytopathology 101:870-877.

Leboldus, J. M., Kinzer, K., Richards, J., Ya, Z., Yan, C., Friesen, T. L., and Brueggeman, R. 2015. Genotype-by-sequencing of the plant-pathogenic fungi Pyrenophora teres and Sphaerulina musiva utilizing Ion Torrent sequence technology. Mol. Plant Pathol. 16:623-632.

Li, H., and Durbin, R. 2009. Fast and accurate short read alignment with Burrows-Wheeler transform. Bioinformatics 25:1754-1760.

Li, H., Vikram, P., Singh, R. P., Kilian, A., Carling, J., Song, J., BurguenoFerreira, J. A., Bhavani, S., Huerta-Espino, J., Payne, T., and Sehgal, D. 2015. A high density GBS map of bread wheat and its application for dissecting complex disease resistance traits. BMC Genomics 16:216.

Liu, M., Rodrigue, N., and Kolmer, J. 2014. Population divergence in the whea leaf rust fungus Puccinia triticina is correlated with wheat evolution Heredity 112:443-453.

Long, D. L., and Kolmer, J. A. 1989. A North American system of nomenclature for Puccinia recondita f.sp. tritici. Phytopathology 79:525-529.

Lu, F., Lipka, A. E., Glaubitz, J., Elshire, R., Cherney, J. H., Casler, M. D., Buckler, E. S., and Costich, D. E. 2013. Switchgrass genomic diversity, ploidy, and evolution: Novel insights from a network-based SNP discovery protocol. PLoS Genet. 9:e1003215.

Mains, E. B., and Jackson, H. S. 1921. Two strains of Puccinia triticina on wheat in the United States. Phytopathology 11:40-45.

Martinez, F., Sillero, J. C., and Rubiales, D. 2005. Pathogenic specialization of Puccinia triticina in Andalusia from 1998 to 2000. J. Phytopathol. 153: 344-349.

Mascher, M., Wu, S., St. Amand, P., Stein, N., and Poland, J. 2013. Application of genotyping-by-sequencing on semiconductor sequencing platforms: A 
comparison of genetic and reference-based marker ordering in barley. PLoS One 8:e76925

McCallum, B. D., Fetch, T., and Chong, J. 2007. Cereal rust control in Canada. Aust. J. Agric. Res. 58:639-647.

Nei, M. 1972. Genetic distance between populations. Am. Nat. 106:283-292.

Nei, M. 1978. Estimation of average heterozygosity and genetic distance from a small number of individuals. Genetics 89:583-590.

Nirmala, J., Drader, T., Lawrence, P. K., Yin, C., Hulbert, S., Steber, C. M., Steffenson, B. J., Szabo, L. J., von Wettstein, D., and Kleinhofs, A. 2011. Concerted action of two avirulent spore effectors activates reaction to Puccinia graminis 1 (Rpg1)-mediated cereal stem rust resistance. PNAS 108:14676-14681.

Ordoñez, M. E., German, S. E., and Kolmer, J. A. 2010. Genetic differentiation within the Puccinia triticina population in South America and comparison with the North American population suggests common ancestry and intercontinental migration. Phytopathology 100:376-383.

Ordoñez, M. E., and Kolmer, J. A. 2007a. Virulence phenotypes of a worldwide collection of Puccinia triticina from durum wheat. Phytopathology 97:344-351.

Ordoñez, M. E., and Kolmer, J. A. 2007b. Simple sequence repeat diversity of a worldwide collection of Puccinia triticina from durum wheat. Phytopathology 97:574-583.

Ordoñez, M. E., and Kolmer, J. A. 2009. Differentiation of molecular genotypes and virulence phenotypes of Puccinia triticina from common wheat in North America. Phytopathology 99:750-758.

Paradis, E. 2010. pegas: An R package for population genetics with an integratedmodular approach. Bioinformatics 26:419-420.

Paradis, E., Claude, J., and Strimmer, K. 2004. APE: Analyses of phylogenetics and evolution in R language. Bioinformatics 20:289-290.

Park, R. F., Burdon, J. J., and Jahoor, A. 1999. Evidence for somatic hybridization in nature of Puccinia recondita f. sp. tritici. Mycol. Res. 103:715-723.

Park, R. F., Jahoor, A., and Felsentstein, F. G. 2000. Population structure of Puccinia recondita in western Europe during 1995, as assessed by variability in pathogenicity and molecular markers. J. Phytopathol. 148:169-179.

Poland, J., Endelman, J., Dawson, J., Rutkoski, J., Wu, S., Manes, Y., Dreisigacker, S., Crossa, J., Sánchez-Villeda, H., Sorrells, M., and Jannink, J. L. 2012b. Genomic selection in wheat breeding using genotyping-bysequencing. Plant Gene 5:103-113.
Poland, J. A., Brown, P. J., Sorrells, M. E., and Jannink, J. L. 2012a. Development of high-density genetic maps for barley and wheat using a novel two-enzyme genotyping-by-sequencing approach. PLoS One 7:e32253.

Poland, J. A., and Rife, T. W. 2012. Genotyping-by-sequencing for plant breeding and genetics. Plant Gene 5:92-102.

Riede, C. R., and Anderson, J. A. 1996. Linkage of RFLP markers to and aluminum tolerance gene in wheat. Crop Sci. 36:905-909.

R Core Team. 2017. R: A Language and Environment for Statistical Computing. R Foundation for Statistical Computing, Vienna, Austria. https://www.Rproject.org/

Roelfs, A. P., Singh, R. P., and Saari, E. E. 1992. Rust Diseases of Wheat: Concepts and Methods of Disease Management. CIMMYT, Mexico, DF.

Rothberg, J. M., Hinz, W., Rearick, T. M., Schultz, J., Mileski, W., Davey, M., Leamon, J. H., Johnson, K., Milgrew, M. J., Edwards, M., and Hoon, J. 2011. An integrated semiconductor device enabling non-optical genome sequencing. Nature 475:348-352.

Saitou, N., and Nei, M. 1987. The neighbor-joining method: A new method for reconstructing phylogenetic trees. Mol. Biol. Evol. 4:406-425.

Singh, R. P., Huerta-Espino, J., Pfeiffer, W., and Figueroa-Lopez, P. 2004 Occurrence and impact of a new leaf rust race on durum wheat in northwestern Mexico from 2001 to 2003. Plant Dis. 88:703-708.

Soleiman, N. H., Solis, I., Soliman, M. H., Sillero, J. C., Villegas, D., Alvaro, F. Royo, C., Serra, J., Ammar, K., and Martínez-Moreno, F. 2016. Short communication: Emergence of a new race of leaf rust with combined virulence to $L r 14 a$ and $L r 72$ genes on durum wheat. Span. J. Agric. Res. 14: e10SC02.

Szabo, L. S., and Kolmer, J. A. 2007. Development of simple sequence repeat markers for the plant pathogenic rust fungus Puccinia triticina. Mol. Ecol. Notes 7:708-710

Wang, X., Bakkeren, G., and McCallum, B. 2010b. Virulence and molecular polymorphisms of the wheat leaf rust fungus Puccinia triticina in Canada from 1997 to 2007. Botany 88:575-589.

Wang, X., Mulock, B., Guus, B., and McCallum, B. 2010a. Development of ESTderived simple sequence repeat markers for wheat leaf rust fungus, Puccinia triticina Eriks. Can. J. Plant Pathol. 32:98-107. 